\title{
Species Richness and Abundance of Bivalves and Gastropods in Mangrove Forests of Casiguran, Aurora, Philippines
}

\author{
Maria Cristina B. Cañada \\ Research and Development Services Office, Aurora State College of Technology, Baler, Aurora, Philippines \\ Email: mariacristinacanada@ascot.edu.ph
}

How to cite this paper: Cañada, M.C.B. (2020) Species Richness and Abundance of Bivalves and Gastropods in Mangrove Forests of Casiguran, Aurora, Philippines. Open Journal of Ecology, 10, 778-787. https://doi.org/10.4236/oje.2020.1012048

Received: October 30, 2020

Accepted: December 5, 2020

Published: December 8, 2020

Copyright ( 2020 by author(s) and Scientific Research Publishing Inc. This work is licensed under the Creative Commons Attribution International License (CC BY 4.0).

http://creativecommons.org/licenses/by/4.0/

\section{(c) (i) Open Access}

\begin{abstract}
The diversity and abundance of bivalves and gastropods were studied from April to July 2015. Two sampling stations, Tinib and Esteves, in Casiguran, Aurora were selected based on the presence of mangrove forest, bivalves, gastropods, muddy substrate, and gleaners for the establishment of a transect line. Each station was laid with 100 meters transect line overlaid continuously with $2 \mathrm{~m} \times 2 \mathrm{~m}$ quadrat along each transect. A total of 50 sampling units covering 0.02 ha area per sampling station were surveyed. The transect line recorded six species of bivalves distributed among five families and 12 species of gastropods belonging to eight families. Three species of bivalves and five species of gastropods were common to both sampling stations. However, Tinib station had most diverse species of bivalves (0.55) while Esteves station had most diverse species of gastropods (0.43). Both stations revealed Dendrostrea folium (43\%) (bivalve) and Cerithidea cingulata (93\%) (gastropods) as most frequently occurring species. Dendostrea folium also emerged as the densest (10,640 ind $\cdot \mathrm{ha}^{-1}$ and 6850 ind $\left.\cdot \mathrm{ha}^{-1}\right)$ and most abundant $(58.52 \%$ and $77.84 \%)$ bivalve species. For gastropods, Terebralia sulcata $(249,250$ ind $\cdot \mathrm{ha}^{-1}$ ) was the densest and most abundant $(96.97 \%)$ in Tinib while Terebralia palustris was the densest $\left(747,050\right.$ ind $\left.\cdot \mathrm{ha}^{-1}\right)$ and most abundant (70.44\%) in Esteves. Pooled results for bivalve species maintained Dendrostrea folium as the densest (8750 ind $\cdot \mathrm{ha}^{-1}$ ) and most abundant (64.81\%). However, for gastropods, Terebralia palustris emerged as the densest $(373,525$ ind $\cdot \mathrm{ha}^{-1}$ ) and most abundant (56.70\%) species. The mangrove forests of Casiguran, Aurora thus contain a variety of bivalves and gastropods with Tinib station dominated by bivalves while Esteves station dominated by gastropods.
\end{abstract}

\section{Keywords}

Diversity, Abundance, Bivalves, Gastropods, Mangrove Forest 


\section{Introduction}

Mangrove forest is composed of salt-tolerant trees and shrubs living in coastal intertidal zone. Its root systems are shallow and partly exposed to the air allowing them to breathe, as these are flooded, during high tide. The roots also serve as barrier, slowing down the movement of tidal waters, aside from serving as habitat and breeding ground for fishes and other marine organisms including mollusks.

The two dominant classes of mollusks present in a mangrove forest are $\mathrm{Bi}$ valves and gastropods. These organisms are living in the mangrove forest at surface substrate, in substrate, and sticking on roots, stems, and mangrove leaves. These take shelter on mangrove roots during high tide and feed on leaf litters making them an important link in the transfer of organic matter from mangroves to the third trophic level such as fish and birds [1].

In Aurora province, out of 430 hectares of mangrove forest, $90 \%$ can be found in Casiguran and Dilasag [2]. Mangrove forests in these municipalities have continually served as sources of bivalves and gastropods for food and income especially by coastal communities. In fact, coastal communities can be commonly seen gleaning for bivalves and gastropods in the morning or in the afternoon during low tide.

In Casiguran, the increase in coastal dwellers, the unprecedented poaching that caused sedimentation, and the continued development of the town in terms of tourism and infrastructure have intensified the extent of exploitation of mangrove forests. The current condition of mangrove forests could affect the population of bivalves and gastropods species and yet these species remain undocumented. Therefore, there is the need to develop a database before a particular bivalve and gastropod species will become extinct in this municipality. This database will serve as basis for conservation and sustainable management of these resources.

This study was conducted to determine the species richness, diversity, frequency, and density of bivalves and gastropods in Casiguran mangrove forests.

\section{Materials and Methods}

Two sampling stations were selected based on the presence of mangrove forest, bivalves, gastropods, muddy substrate, and gleaners for the establishment of a transect line. One sampling station in Tinib and one in Esteves, both located in Casiguran, Aurora, Philippines (Figure 1).

Random shell collection within mangrove forests was done to obtain data on the number of species found including their economic importance. For transect survey, one 100 meters transect line was laid parallel to the intertidal zone. This was overlaid continuously with a $2 \mathrm{~m} \times 2 \mathrm{~m}$ quadrat along the transect line. A total of 50 sampling units covering 0.02 ha area per sampling station were surveyed.

Each quadrat was surveyed by two observers gleaning along in one direction 


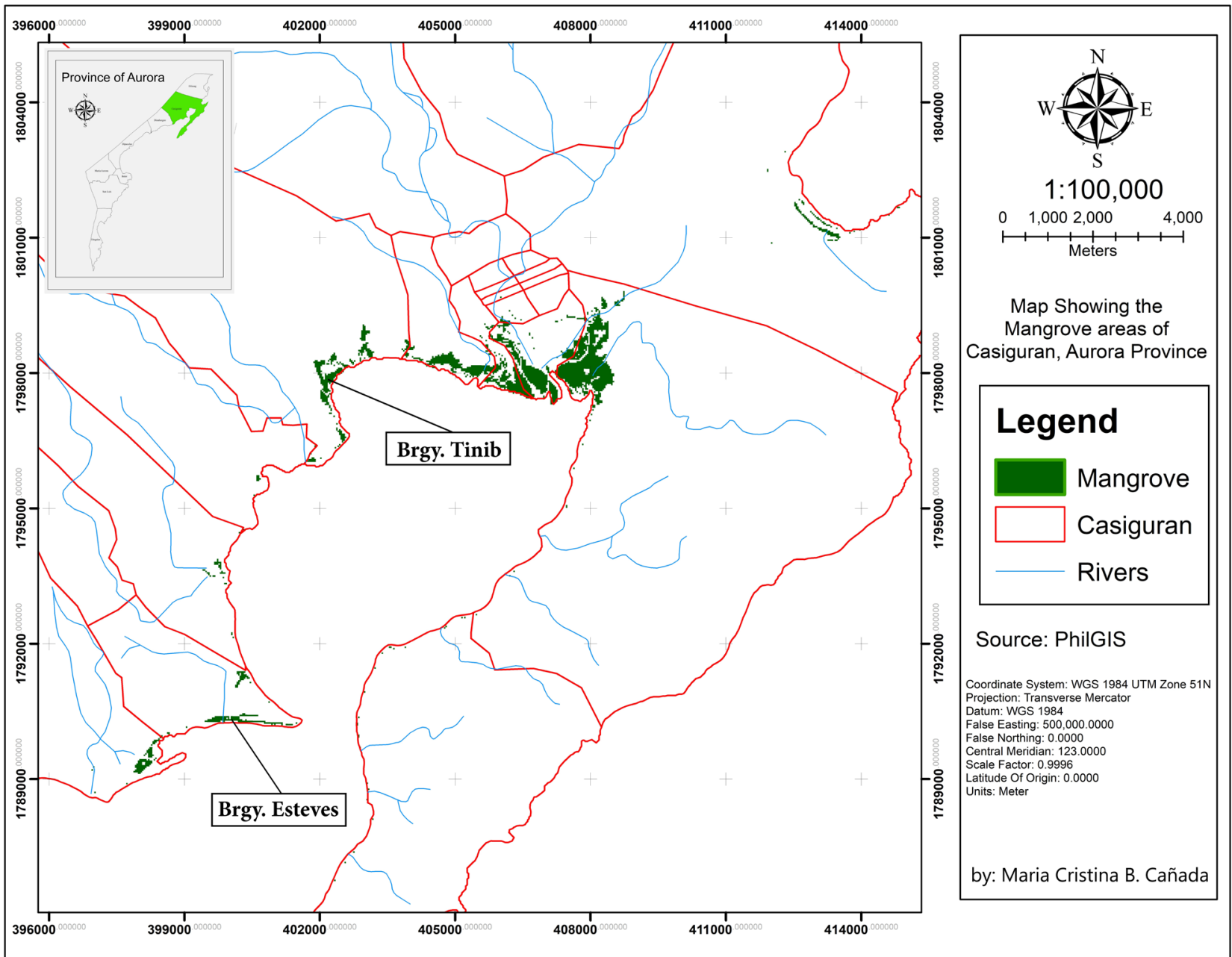

Figure 1. Location of the study site.

parallel to the length of the transect line. Gleaning was done by handpicking of epifaunal species. However, for infaunal species, a bolo was used in digging the substratum to a depth of $15 \mathrm{~cm}$.

All live bivalves and gastropods found inside each quadrat were photographed, identified, counted, and listed on the field notebook. Representative samples of each species were collected and preserved for future reference.

The surveys were conducted during the months of April to July 2015 during the lowest tide of the day. The GPS coordinates of each mangrove forest were taken for mapping purposes using Garmin Etrex-10.

\section{Data Analysis}

The following formulae were used in the analysis of data:

The species diversity was computed using Simpson's Diversity Index $\left(D_{s}\right)$ :

$$
D_{s}=\frac{\sum n_{i}\left(n_{i}-1\right)}{N(N-1)}
$$

where: 
$n_{i}=$ number of individuals of the species.

$N=$ total number of individuals in the sample.

The species frequency was obtained from the index $(C)$ :

$$
C=\frac{P}{N} \times 100
$$

where:

$P=$ number of quadrats containing the species.

$N=$ total number of quadrats.

The population density per species was calculated based on the index $(D)$ :

$$
D=\frac{n_{i}}{A}
$$

where:

$n_{i}=$ total number of individuals per species.

$A=$ total area covered in hectares.

The relative abundance per species was based on the index (\% $A b)$ :

$$
\% A b=\frac{D}{\sum D}
$$

where:

$D=$ population density per species.

$\sum D=$ the sum total of all population densities of all species.

\section{Results and Discussion}

\subsection{Species Richness}

A total of 6 bivalves and 12 gastropods were found during a random shell collection within the mangrove forest (Table 1). More bivalves were found in Tinib (5 species) while more gastropods were found in Esteves (11 species).

The Tinib sampling station had higher tree density 2300 ind.ha ${ }^{-1}$ distributed in a wider and longer continuous stretch of mangrove forest as compared to the Esteves station (1050 ind.ha ${ }^{-1}$ ). This station had more mangrove roots that served as shelter and attachment sites for bivalves during high tide. The presence of Isognomon ephippium in Tinib indicates the presence of a suitable habitat for this species that requires being attach to a solid substrate such as mangrove roots [3]. In addition, the mudflats within the mangrove forest were observed as most preferred by epifaunal bivalve species (Glauconome virrens, Isognomon ephippium, and Gafrarium tumidum). Gafrarium tumidum species is also found in mud within mangrove forest in Sri Lanka [4].

The abundant number of gastropods than bivalves in Esteves station could be attributed to the nature of the species that are adapted to various macrohabitat of the mangrove system [1]. This station had muddy sand substrate where gastropods can just freely graze for organic matter available and then move up the tree during high tide to avoid immersion. Physical factors such as sediment type affect the distribution of mangrove gastropod species [5]. 
Table 1. Bivalves and gastropods found in mangroves forests of Casiguran, Aurora.

\begin{tabular}{|c|c|c|c|c|c|}
\hline Family Name & Scientific Name & Local Name & Tinib & Estev-es & Eco-nomic Use \\
\hline \multicolumn{6}{|l|}{ Bivalves } \\
\hline Glauconomidae & Glauconome virens & Kimpi & + & - & Food \\
\hline Isognomonidae & Isognomon ephippium & Lapes & + & - & Food \\
\hline Mytilidae & Modiolus aratus & Ubet ng Agta & - & + & Food \\
\hline Ostreidae & Dendrostrea folium & Sise & + & + & Food \\
\hline \multirow[t]{2}{*}{ Veneridae } & Gafrarium tumidum & Parek & + & + & Food \\
\hline & Pitar citrinus & Gume-gumean & + & + & Food \\
\hline \multicolumn{6}{|l|}{ Gastropods } \\
\hline Columbellidae & $S p 1$ & - & - & + & Food \\
\hline Littorinadae & Littoraria scabra & Buteng & + & + & Food \\
\hline Melongenidae & Volema myristica & Alan-alan & + & + & Food \\
\hline Muricidae & Cronia margariticola & - & - & + & Food \\
\hline \multirow[t]{3}{*}{ Neritidae } & Nerita planospera & Katte & + & + & Food \\
\hline & Nerita chameleon & Katte & - & + & Food \\
\hline & Nerita polita & - & - & + & Food \\
\hline \multirow[t]{3}{*}{ Potamididae } & Cerithidea cingulata & Balilit & + & + & Food \\
\hline & Terebralia sulcata & Balilit & + & & Food \\
\hline & Terebralia palustris & Balilit & - & + & Food \\
\hline Trochidae & Monodontia labio & Buteng & + & + & Food \\
\hline Turbinidae & Turbo cinereus & Buteng & - & + & Food \\
\hline
\end{tabular}

This result was lower than what was obtained in mangrove forest of Catanduanes, Philippines that recorded a total of 27 gastropods and 30 bivalves [6]. However, the families with several species found were similar to this work. These families include Veneridae (2 species), Potamididae (3 species) and Neritidae (3 species).

All species found in Tinib and Esteves were exploited by the coastal dwellers living within the study sites as source of food and additional source of income.

\subsection{Species Diversity}

The transect survey revealed Tinib sampling station to have the most diverse species of bivalves (0.55) (Table 2). The bivalves found in Tinib were infaunal species that are suited in the mudflat. In addition, the wider stretch of mangrove forest with tree density of 2300 ind.ha ${ }^{-1}$ as compared with Esteves station (1050 ind $\cdot \mathrm{h}^{-1}$ ) provided more roots branching underground that served as anchor for bivalves during high tide. The higher abundance of bivalves in mangrove forest could be due to the presence of root branching which are used by bivalves in clinging on [7]. 
Table 2. Species diversity (Ds) of bivalves per sampling station.

\begin{tabular}{|c|c|c|c|c|c|}
\hline \multirow{2}{*}{ Family Name } & \multirow{2}{*}{ Species Name } & \multicolumn{2}{|c|}{ Tinib (muddy sand) } & \multicolumn{2}{|c|}{ Esteves (sandy mud) } \\
\hline & & $\mathbf{n}$ & $n(n-1)$ & $\mathrm{n}$ & $n(n-1)$ \\
\hline Glauconomidae & Glauconome virens & 20 & 380 & 0 & 0 \\
\hline Isognomonidae & Isognomon ephippium & 13 & 156 & 0 & 0 \\
\hline Mytilidae & Modiolus aratus & 0 & 0 & 17 & 272 \\
\hline Ostreidae & Dendrostrea folium & 213 & 45,156 & 137 & 18,632 \\
\hline \multirow[t]{2}{*}{ Veneridae } & Gafrarium tumidum & 118 & 13,806 & 14 & 182 \\
\hline & Pitar citrinus & 0 & 0 & 8 & 56 \\
\hline$\sum n(n-1)$ & & \multicolumn{2}{|c|}{59,498} & \multicolumn{2}{|c|}{19,142} \\
\hline Total (N) & & \multicolumn{2}{|c|}{364} & \multicolumn{2}{|c|}{176} \\
\hline Species Diversity $(D s)$ & & \multicolumn{2}{|c|}{0.55} & \multicolumn{2}{|c|}{0.38} \\
\hline
\end{tabular}

Gastropods in Esteves were diverse (0.43) (Table 3). This station had muddy sand substrate with sparsely populated mangrove forest $\left(1050\right.$ ind $\left.\cdot h a^{-1}\right)$ forming an islet. The substrate could either be dry or wet depending on its sun exposure during low tide such that species like Litoraria scabra can be found on dry and wet areas but more commonly seen attached singly or in groups on young tree stems.

\subsection{Species Frequency}

Dendrostrea folium revealed as the most frequently occurring bivalve species in both Tinib and Esteves (43\%) (Table 4). This species was commonly found attached to mangrove roots, stems, and leaves of young mangrove trees in groups. This species belongs to the Ostreidae family which also exhibited as the most abundant family in mangrove forest in Indonesia [7]. On the other hand, Gafrarium tumidum was found common in muddy substrates of both stations.

Cerithidea cingulata was the most frequently occurring species in both Tinib and Esteves (93\%) (Table 5). This same species was also found common in mangrove forests in Sri Lanka [4]. This could be attributed to the ability of this species to inhabit in the mud, cling on roots, and attach to stems of mangroves.

\subsection{Species Density}

Dendrostrea folium revealed as the most dense (10,650 ind.ha ${ }^{-1}$ and 6850 ind.ha ${ }^{-1}$ ) and most abundant (58.52\% and 77.84\%) bivalve species in Tinib and Esteves (Table 6). This species can be found in mangrove swamps in the Philippines feeding on algae or detritus [8]. The presence of coastal dwellers adds up to the increase of detritus in the area that serves as food for this species.

Gastropods belonging to Potamididae family were found as most dense in $\mathrm{Ti}$ nib and Esteves stations (Table 7). In particular, Cerithidea cingulata was most dense $\left(249,250\right.$ ind.ha $\left.{ }^{-1}\right)$ and most abundant $(96.97 \%)$ in Tinib while Terebralia palustris was most dense $\left(747,050\right.$ ind $\left.\cdot \mathrm{ha}^{-1}\right)$ and most abundant $(70.44 \%)$ in 
Table 3. Species diversity $(D s)$ of gastropods per sampling station.

\begin{tabular}{|c|c|c|c|c|c|}
\hline \multirow{2}{*}{ Family Name } & \multirow{2}{*}{ Species Name } & \multicolumn{2}{|c|}{ Tinib (muddy sand) } & \multicolumn{2}{|c|}{ Esteves (sandy mud) } \\
\hline & & $\mathbf{n}$ & $\mathrm{n}(\mathrm{n}-1)$ & $\mathbf{N}$ & $n(n-1)$ \\
\hline Columbellidae & $S p 1$ & 0 & 0 & 13 & 156 \\
\hline Littorinadae & Littoraria scabra & 41 & 1640 & 70 & 4830 \\
\hline Melongenidae & Volema myristica & 12 & 132 & 33 & 1056 \\
\hline Muricidae & Cronia margariticola & 0 & 0 & 148 & 21,756 \\
\hline \multirow[t]{3}{*}{ Neritidae } & Nerita planospera & 8 & 56 & 9 & 72 \\
\hline & Nerita chameleon & 0 & 0 & 190 & 35,910 \\
\hline & Nerita polita & 0 & 0 & 2 & 2 \\
\hline \multirow[t]{3}{*}{ Potamididae } & Cerithidea cingulata & 4985 & $24,845,240$ & 5800 & $33,634,200$ \\
\hline & Terebralia sulcata & 91 & 8190 & 0 & 0 \\
\hline & Terebralia palustris & 0 & 0 & 14,941 & $223,218,540$ \\
\hline Trochidae & Monodontia labio & 4 & 12 & 3 & 6 \\
\hline Turbinidae & Turbo cinereus & 0 & 0 & 1 & 0 \\
\hline$\sum \mathrm{n}(\mathrm{n}-1)$ & & \multicolumn{2}{|c|}{$24,855,270$} & \multicolumn{2}{|c|}{$256,916,528$} \\
\hline Total (N) & & \multicolumn{2}{|c|}{5141} & \multicolumn{2}{|c|}{21,210} \\
\hline Species Diversity $(D s)$ & & \multicolumn{2}{|r|}{0.06} & \multicolumn{2}{|r|}{0.43} \\
\hline
\end{tabular}

Table 4. Frequency of bivalve species found per sampling station.

\begin{tabular}{|c|c|c|c|c|}
\hline Family Name & Species Name & $\begin{array}{c}\text { Tinib } \\
\text { (muddy sand) }\end{array}$ & $\begin{array}{c}\text { Esteves } \\
\text { (sandy mud) }\end{array}$ & $\begin{array}{c}\text { Species } \\
\text { Frequency } \\
(\%)\end{array}$ \\
\hline Glauconomidae & Glauconome virens & +++++ & - & 5 \\
\hline Isognomonidae & Isognomon ephippium & ++ & - & 2 \\
\hline Mytilidae & Modiolus aratus & - & +++ & 3 \\
\hline Ostreidae & Dendrostrea folium & $\begin{array}{c}++++++++++ \\
++++++++++ \\
+++++\end{array}$ & $\begin{array}{c}++++++++++ \\
++++++++\end{array}$ & 43 \\
\hline \multirow[t]{2}{*}{ Veneridae } & Gafrarium tumidum & $\begin{array}{c}++++++++++ \\
++++++++++ \\
+++\end{array}$ & +++++ & 28 \\
\hline & Pitar citrinus & - & +++++ & 5 \\
\hline
\end{tabular}

$$
+=2 \times 2 \text { m quadrat. }
$$

Table 5. Frequency of gastropod species found per sampling station.

\begin{tabular}{lcccc}
\hline Family Name & Species Name & $\begin{array}{c}\text { Tinib } \\
\text { (muddy sand) }\end{array}$ & $\begin{array}{c}\text { Esteves } \\
\text { (sandy mud) }\end{array}$ & $\begin{array}{c}\text { Species } \\
\text { Frequency } \\
\text { (\%) }\end{array}$ \\
\hline Columbellidae & $S p 1$ & - & ++++ & 4 \\
Littorinadae & Littoraria scabra & +++++++ & ++++++ & 15 \\
\hline
\end{tabular}




\section{Continued}

\begin{tabular}{|c|c|c|c|c|}
\hline Melongenidae & Volema myristica & $\begin{array}{c}++++++++++ \\
+\end{array}$ & $\begin{array}{c}++++++++++ \\
+++++\end{array}$ & 26 \\
\hline Muricidae & Cronia margariticola & - & $\begin{array}{c}++++++++++ \\
++++++++++ \\
+++\end{array}$ & 23 \\
\hline \multirow[t]{3}{*}{ Neritidae } & Nerita planospera & +++++ & +++++ & 10 \\
\hline & Nerita chameleon & - & $\begin{array}{c}++++++++++ \\
++++++++++ \\
+++++++++++ \\
++++++\end{array}$ & 36 \\
\hline & Nerita polita & - & + & 1 \\
\hline \multirow[t]{3}{*}{ Potamididae } & Cerithidea cingulata & $\begin{array}{c}++++++++++ \\
++++++++++ \\
++++++++++ \\
++++++++++ \\
+++++++++\end{array}$ & $\begin{array}{c}++++++++++ \\
++++++++++ \\
++++++++++ \\
++++++++++ \\
++++\end{array}$ & 93 \\
\hline & Terebralia sulcata & $\begin{array}{c}+++++++++ \\
++++++++\end{array}$ & - & 18 \\
\hline & Terebralia palustris & - & $\begin{array}{c}++++++++++ \\
++++++++++ \\
++++++++++ \\
++++++++++ \\
++++\end{array}$ & 44 \\
\hline Trochidae & Monodontia labio & ++ & + & 3 \\
\hline Turbinidae & Turbo cinereus & - & + & 1 \\
\hline
\end{tabular}

$+=2 \times 2$ m quadrat.

Table 6. Density $(D)$ and relative abundance $(\% A b)$ of bivalve species per sampling station.

\begin{tabular}{cccccccc}
\hline \multirow{2}{*}{ Family Name } & \multirow{2}{*}{ Species Name } & \multicolumn{2}{c}{ Tinib } & \multicolumn{2}{c}{ Esteves } & \multicolumn{2}{c}{ Pooled } \\
\cline { 3 - 7 } & & $D$ & $\% A b$ & $D$ & $\% A b$ & $D$ & $\% \boldsymbol{A b}$ \\
\hline Glauconomidae & Glauconome virens & 1000 & 5.49 & 0 & 0 & 500 & 3.70 \\
Isognomonidae & Isognomon ephippium & 650 & 3.57 & 0 & 0 & 325 & 2.41 \\
Mytilidae & Modiolus aratus & 0 & 0 & 850 & 9.66 & 425 & 3.15 \\
Ostreidae & Dendrostrea folium & 10,650 & 58.52 & 6850 & 77.84 & 8750 & 64.81 \\
Veneridae & Gafrarium tumidum & 5900 & 32.42 & 700 & 7.95 & 3300 & 24.44 \\
& Pitar citrinus & 0 & 0 & 400 & 4.55 & 200 & 1.48
\end{tabular}

Table 7. Density $(D)$ and relative abundance $(\% A b)$ of gastropod species per sampling station.

\begin{tabular}{lcccccccc}
\hline \multirow{2}{*}{ Family Name } & \multirow{2}{*}{ Species Name } & \multicolumn{2}{c}{ Tinib } & \multicolumn{2}{c}{ Esteves } & \multicolumn{2}{c}{ Pooled } \\
\cline { 3 - 8 } & & $D$ & $\% A b$ & $D$ & $\% A b$ & $D$ & $\% A b$ \\
\hline Columbellidae & $S p 1$ & 0 & 0 & 650 & 0.06 & 325 & 0.05 \\
\hline
\end{tabular}




\begin{tabular}{|c|c|c|c|c|c|c|c|}
\hline Continued & & & & & & & \\
\hline Littorinadae & Littoraria scabra & 2050 & 0.80 & 3500 & 0.33 & 2775 & 0.42 \\
\hline Melongenidae & Volema myristica & 600 & 0.23 & 1650 & 0.16 & 1125 & 0.17 \\
\hline Muricidae & Cronia margariticola & 0 & 0 & 7400 & 0.70 & 3700 & 0.56 \\
\hline Neritidae & Nerita planospera & 400 & 0.16 & 450 & 0.04 & 425 & 0.06 \\
\hline & Nerita chameleon & 0 & 0 & 9500 & 0.90 & 4750 & 0.72 \\
\hline & Nerita polita & 0 & 0 & 100 & 0.01 & 50 & 0.008 \\
\hline Potamididae & Cerithidea cingulata & 249,250 & 96.97 & 290,000 & 27.35 & 269,625 & 40.93 \\
\hline & Terebralia sulcate & 4550 & 1.77 & 0 & 0 & 2275 & 0.35 \\
\hline & Terebralia palustris & 0 & 0 & 747,050 & 70.44 & 373,525 & 56.70 \\
\hline Trochidae & Monodontia labio & 200 & 0.08 & 150 & 0.014 & 175 & 0.03 \\
\hline Turbinidae & Turbo cinereus & 0 & 0 & 50 & 0.005 & 25 & 0.004 \\
\hline Total & & 257,050 & & $1,060,500$ & & 658,775 & \\
\hline
\end{tabular}

Esteves. A higher density of Potamididae $\left(151 \mathrm{ind} / \mathrm{m}^{2}\right)$ in a mangrove area can also be found in Aceh Besar and Banda Aceh districts in Indonesia [7].

\section{Conclusion}

Based on the results, the following conclusions are drawn: The mangrove forests of Casiguran, Aurora contain a variety of bivalves and gastropods with economic value, most bivalve species belong to the family Veneridae (two species) while most gastropods belong to Potamididae (three species) and Neritidae (three species) families, the diverse species of bivalves found in Tinib is because of the wider stretch of mangrove forest that provided more roots branching underground for bivalves to anchor during high tide, the rich gastropods species found in Esteves could be due to the active nature of the organism that enables them to go up and down the mangrove tree following the tide, the dense (10,650 ind $\cdot \mathrm{ha}^{-1}$ and 6850 ind $\cdot \mathrm{ha}^{-1}$ ) and abundant (58.52\% and 77.84\%) Dendrostrea folium in both Tinib and Esteves could be due to coastal dwellers adding up detritus that serve as food for these organisms, and the dense and abundant family of Potamididae could be attributed to the species adaptation on environmental condition in the sampling sites.

\section{Recommendations}

For a more comprehensive survey of bivalves and gastropods species found in mangrove forests of Casiguran, Aurora, it is recommended that the following factors be included: the survey must be conducted for 12 months to cover the changes of species richness and abundance during different seasons, the substrate must be analyzed to determine the organic matter content and soil texture, the population structures of bivalves, gastropods and mangrove trees be analyzed to determine the relationship between the size of mangrove trees and abundance of bivalves and gastropods. 


\section{Acknowledgements}

I would like to extend our heartfelt gratitude to the Department of Agriculture-Bureau of Agricultural Research (DA-BAR) for funding this study, to the project consultant, Dr. Teodora U. Bagarinao of Southeast Asian Fisheries and Development Center (SEAFDEC) for species identification, to the project staff and enumerators for providing the data and to the then ASCOT Research and Development Services Office Director, Dr. Eutiquio L. Rotaquio for guiding us in the processing of important documents needed for fieldwork activities.

\section{Conflicts of Interest}

The author declares no conflicts of interest regarding the publication of this paper.

\section{References}

[1] Kabir, M., Abolfathi, M., Zahedi, S., Kathiresan, K. and Goli, S. (2014) Effect of Mangroves on Distribution, Diversity and Abundance of Molluscs in Mangrove Ecosystem: A Review. AACL Bioflux, 7, 286-300.

[2] Aurora Integrated Area Development Project II (AIADP-II) (1996) A Management and Protection Strategy for Aurora Province. AIADP-II Project Management Office, Baler, Aurora.

[3] Nasution, S. and Zulkifli (2014) Species Richness and Abundance of Bivalvia and Gastropoda (Molluscs) in Mangrove Forest of Dumai City, Riau Province. International Journal of Innovation and Applied Studies, 9, 1981-1986.

[4] De Silva, M. and De Silva, P.K. (1998) Status, Diversity and Conservation of the Mangrove Forests of Sri Lanka. Journal of South Asian Natural History, 3, 79-102.

[5] Cantera, J.R., Thomassin, B.A. and Arnaud, P.M. (1999) Faunal Zonation and Assemblages in the Pacific Colombian Mangroves. Hydrobiologia, 413, 17-33. https://doi.org/10.1023/A:1003890826741

[6] Masagca, J.T., Mendoza, A.V. and Tribiana, E.T. (2010) The Status of Mollusk Diversity and Physical Setting of the Mangrove Zones in Catanduanes Island, Luzon, Philippines. Biotropa, 17, 62-76. https://doi.org/10.11598/btb.2010.17.2.77

[7] Irma, D. and Sofyatuddin, K. (2012) Diversity of Gastropods and Bivalves in Mangrove Ecosystem Rehabilitation Areas in Aceh Besar and Banda Aceh Districts, Indonesia. Aquaculture, Aquarium, Conservation and Legislation. International Journal of Bioflux Society, 5, 55-59.

[8] Carpenter, K.E. and Niem, V.H. (Eds.) (1998) FAO Species Identification Guide for Fishery Purposes. The Living Marine Resources of the Western Central Pacific. Vol. 1. Seaweeds, Corals, Bivalves and Gastropods. Rome, FAO, 1-686. 